\title{
THE LINDSAEOID FERNS OF THE OLD WORLD I. NEW CALEDONIA
}

\author{
K. U. KRAMER \\ ILlUSTRATIONS BY W. H. A. HEKKING \\ (Botanical Museum and Herbarium, University of Utrecht)
}

(received November 19th, 1965)

\section{INTRODUCTION AND PHYTOGEOGRAPHIC NOTES}

The present paper is the first of a series of regional revisions of the Old World Lindsaeoid ferns centering around a revision of the group in the Flora Malesiana area where the largest number of species occurs. In the few cases where modern revisions are already available the present author's contribution will be limited to critical and additional notes; otherwise they will be in the nature of monographic treatments, although widespread species will, of course, as a rule not be described more than once.

The botanically isolated position of New Caledonia is well-known, and most floristic phytogeographers agree in regarding it as a separate floristic region (e.g. Good, 1947; VAN Balgooy, 1960). Endemism is high in the ferns as well as in the flowering plants, although the number of endemic fern genera is very small (BROWNLIE, 1965). In the absence of a comprehensive modern fern flora I am unable to quote any reliable figures. The last paper dealing with the New Galedonian fern flora as a whole by Fournier (1873) is nearly 100 years old. Later contributions were made notably by CopeLAND (1929b), Christensen (in: Däniker, 1932), and Guillaumin (19621964). Christ (1910), on the basis of Fournier's (1873) data, reported 259 species, 86 endemic, but stated that FournIER's species concept was apparently too narrow (p. 234), which I can confirm for the Lindsaea group, as shown by the synonymy in the present paper. On the other hand, additional species have been found or distinguished since. A more important factor limiting our knowledge of endemism in the New Caledonian ferns (and other plants) is, I think, the poor state of knowledge of the Melanesian flora, particularly of the Solomon Islands. The exploration that is now in progress in this archipelago may be expected to furnish important additional data.

As far as our present knowledge goes, 14 species of Lindsaeoid ferns occur in New Caledonia; 8 of them are endemic. (The Isle of Pines and the Loyalty Islands form part of the New Caledonian floristic region. The Isle of Pines is not considered separately here, and I have seen no collections of ferns from the group under discussion from the Loyalty Islands.) A discussion of their affinity should not only deal with the non-endemics but also include data on the distribution of the relatives of the endemic species. In the present group 
this is not an easy task as some of them occupy rather isolated positions.

The monotypic section Davalliastrum is very peculiar in the genus Lindsaea and not very close to any other group. In my opinion it is near the common source of the genera Lindsaea, Tapeinidium; and Sphenomeris, and it can be assigned only with difficulty to a genus (see p. 569). Lindsaea vieillardii has no close relatives but its affinities seem to be with $L$. ensifolia. $L$. nervosa, $L$. prolongata, and $L$. rufa form a natural group near $L$. ensifolia and $L$. heterophylla in Schizoloma, treated as a genus by some modern authors (HoLTtuM, 1957; BRowNLIE, 1961), sometimes under the superfluous name Schizolegnza (TARDIEU-BLot, 1958), and maintained by myself (1958) as a subgenus; I now prefer to treat it as a section, with Holttum's circumscription (see p. 571). Lindsaea francii belongs to a group of closely related Malesian species. Sphenomeris angustifolia seems to belong near the very widespread gerontogean Sph. chinensis which also occurs in New Caledonia; Sph. alutacea is probably related to an E. MalesianW. Pacific species. The distribution of the non-endemic species is stated in the taxonomic treatment; there is an Australian-New Zealand element (2 spp.), a South Pacific element (2 spp.), and a general paleotropical element (2 spp.).

When the assortment of Lindsaeoid ferns of New Caledonia is compared with that of other, physiographically \pm similar islands in the tropical parts of the Pacific, we find a striking absence of the group Lindsaea subgenus Odontoloma which extends far into the Pacific with some very widespread species, e.g. L. repens (macraeana) to Hawaii, L. rigida to Tahiti. Other examples might be cited. This peculiarity New Caledonia shares to some extent with tropical Australia.

\section{Ecology AND Distribution ON THE ISLAND}

Many collections are without or with scanty ecological data. If any, they are summed up under the species.

Equally little can be said about the distribution in New Caledonia. The localities from which most species are known are concentrated in the South, but this is presumably due to the location of the capital in that part of the island.

\section{Materials; ackNowledgements}

The herbaria in which the specimens are located that served for this study are cited with their standard abbreviations now in general use: I am greatly indebted to the Directors and Curators of these herbaria who sent their material on loan or permitted me to study it in place. My particular thanks go to Mme. M. Tardieu-Blot, Laboratoire de Phanérogamie, Muséum National d'Histoire Naturelle, Paris, for giving me access to the very rich New Caledonian collections in the herbarium of that institute and for generously giving some valuable duplicates to the Utrecht herbarium. The time spent at Paris was 
unfortunately insufficient to study all the material there, and in the case of common species the citations from that herbarium are therefore incomplete.

A word of caution about the numbers of Franc's, and, to a lesser extent, Vieillard's New Caledonian specimens seems to be in place. They were apparently sorted to species and then numbered long after they had been collected, and a certain number on the label expresses some botanist's opinion on the species the specimen belongs to, rather than a particular place and date of the collection. These numbers are cited below with quotation marks.

\section{TAXONOMIC PART ${ }^{1}$ )}

Key to the genera (based on New Caledonian species):

1. Lamina simply pinnate or bipinnate with a conform terminal pinna . . . . . . . . . . . . Lindsaea

- Lamina decompound, i.e., at least bipinnate and without a conform terminal pinna . . . . . . . . . 2

2. Ultimate divisions cuneate or linear; indusia attached at the sides for at least half their width ...... Sphenomeris

- Ultimate divisions not cuneate or linear, or, if so, the indusium laterally quite free .......... Lindsaea

Key to the species:

\section{Sphenomeris Maxon}

1. Primary pinnae with a terminal pinnule similar to the lateral ones.. . . . . . . . . . . . . . . . 3. Sph. alutacea - Upper pinnules reduced, confluent, the primary pinnae without a terminal pinnule . . . . . . . . . . . 2

2. Larger sori on $4-8$ vein-ends $\ldots$

- Sori on 1 or 2 vein-ends . . . . . . . . . 3

3. Ultimate segments rigid, with revolute margin; scales ovate, with acicular apex; spores trilete ............ . . Sph. angustifolia

- Ultimate segments not rigid, the margin not revolute; scales entirely acicular; spores monolete. . . . . . . . . . . 2. Sph. chinensis

1. Sphenomeris angustifolia (Bernh.) Brownlie, Trans. Roy. Soc. N. Zeal. 87: 196, 1959. Basionym: Lindsaea angustifolia Bernhardî, Schr. Akad. Erfurt 14, fig. 6, 1802, based on: Adiantum clavatum Forster, Flor. Ins. Austr. Prodr. 83, 1786, non L., 1753 [which is Sph. clavata (I.) Maxon]. - Odontosoria angustifolia (Bernh.) C. Chr.; Ind. Fil. 464, 1906. - Stenoloma angustifolium (Bernh.) C. Chr., Ind. Fil. Suppl. III : 173, 1934. - Davallia forsteri Carruthers ex Seemann, Fl. Vit. 339, 1873, nom. invalid. in synon. - Microlepia forsteri (Carr. ex Seem.) Armstrong, Trans. N. Zeal. Inst. 13: 364, 1881. - Type: a specimen without data numbered 459 (BM!).

Lindsaea scoparia Mettenius, Ann. Sci. Nat. IV. 15: 64, 1861. - Davallia scoparia (Mett.) Hooker in Hooker and Baker, Syn. Fil. 1st ed. 101, 1867. - Microlepia scoparia (Mett.) Garruthers ex Seemann, Fl.

1) For the terminology, see Kramer (1957). 
Vit. 340, 1873. - Schizoloma scoparium (Mett.) Kuhn, Chaetopt. 346, t. 1 fig. 1, 1882. - Odontosoria scoparia (Mett.) Diels in Engler und Prantl, Nat. Pfl. I4: 215, 1899. - Sphenomeris scoparia (Mett.) Copeland, Univ. Calif. Publ. Bot. 14: 366, 1929. - Stenoloma scoparium (Mett.) C. Chr., Ind. Fil. Suppl. III: 173, 1934. - Lectotype: Vieillard 1550, Balade (P!).

Not Davallia remota Kaulfuss, cited by Duperrex '(teste Fournier, 1873), which was described from Hawaii and belongs to the next species.

This species in habit closely resembles the narrower form of $S p h$. chinensis; the principal differences are given in the key. Scales fuscous, to $2 \mathrm{~mm}$ long, to nearly $1 \mathrm{~mm}$ wide at base. Sori binerval; indusium pale, $0.4 \mathrm{~mm}$ broad, not quite reaching the margin, the sides attached for about half their length, sometimes flanked by a small tooth on the latero-apical extremity of the segment. Spores medium brown, trilete, ca. $35 \mu$.

Fig. $1 \mathrm{~A}, 3 \mathrm{~A}$

Distribution: endemic.

Ecology: by mountain streams, torrents, etc., $400-500 \mathrm{~m}$. The plant has the appearance of a rheophyte.

Selected citations:

Vieillard 1550, Balade (lectotype of $L$. scoparia, $P$; isotypes $B, K$ ); id. $1550-$ 1551-1552, Wagap (B, K, L, P, Pic.-Ser.); Franc 1428, Tao (P); Sarasin 7, above Oubatche $(P, Z)$; Le Rat 1115, s.l. (P).

2. Sphenomeris chinensis (L،) Maxon, Jo. Wash. Acad. Sci. 3: 144, 1913. Basionym: Trichomanes chinense L., Spec. Plant. 2: 1099, 1753. - Type: Osbeck s.n., China (S-PA!).

Adiantum chusanum L., Spec. Plant. 2: 1095, 1753. - Sphenomeris chusana (L.) Copeland, B. P. Bishop Mus. Bull. 59: 69, 1929. - Type: coll.?, China (LINN!).

Adiantum tenuifolium Lamarck, Encycl. I: 44, 1783. - Davallia tenuifolia (Lam.) Swartz, Schrad. Journ. 18002: 88, 1801; Fournier, Ann. Sci. Nat. V. 18: 338, 1873. - Lindsaea tenuifolia (Lam.) Mettenius, Ann. Sci. Nat. IV. 15: 64, 1861. - Type: Sonnerat s.n. from 'India' (P!). Trichomanes cuneiforme Forster, Flor. Ins. Austr. Prodr. 85, 1786. - Davallia cuneiformis (Forster) Swartz, Schrad. Journ. 18002: 87, 1801. - Type: a specimen without data, possibly from New Caledonia, numbered 306 and 469 (BM!).

It is not necessary to give here a description of this well-known species which is very widespread in the tropical and warm-temperate parts of the Eastern Hemisphere, but is apparently absent from Australia and New Zealand.

The arguments for adopting the name Sphenomeris chinensis instead of Sph. chusana, mostly used in recent literature, will be explained elsewhere, where the full synonymy will also be given.

Ecology: open places, by trails and rivulets, to at least $800 \mathrm{~m}$. Described as psammophilous by Virot. . 
Selected citations:

Franc '667', Dumbéa (BRI, K, MICH); id. '667', Ouaouo (BRI, GH, K, L, US); id. '667', Col d'Amieu, La Toa (B, BRI, GH, MICH, US, Z); Virot 736. Hienghene (A); Le Rat 556, Mt. Mou (B); Vieillard 1548, Wagap (B, GH, L); McKee 2532, Hienghène (U); id. 3171, Vallée de Thy (US).

3. Sphenomeris alutacea (Mett.) Copeland, Univ. Calif. Publ. Bot. 14: 365, 1929. Basionym: Lindsaea alutacea Mettenius, Ann. Sci. Nat. IV. 15: 63, 1861. - Schizoloma alutaceum (Mett.) Kuhn, Chaetopt. 346, 1882. - Stenoloma alutaceum (Mett.) G. Chr., Ind. Fil. Suppl. III: 173, 1934. - Lectotype: Vieillard 1554, Kanala (P!).

Rhizome rather long-creeping, 2-3 $\mathrm{mm}$ in diam., with an internal sclerotic strand; scales lustrous, dark reddish brown to castaneous, with 3 rows of cells at the base and a very long apex of one row of cells, up to $5 \mathrm{~mm}$ long. Petioles close to rather remote, fawn-coloured, abaxially rounded to obtusely bi-angular, slender, up to ca. 20 cm long, 1-1 $\frac{1}{2} \times$ as long as the lamina. Lamina subcoriaceous to coriaceous, drying brown, narrowly oblong, bipinnate or tripinnate at base, the apex gradually of simpler structure; pinnate or bipinnate pinnae ca. 6-9 to a side, obliquely ascending, short-petiolulate, axes slender. Ultimate pinnules triangular-cuneate, the larger ones irregularly, asymmetrically, and shallowly incised from the apical margin, about $10 \mathrm{~mm}$ long and $6 \mathrm{~mm}$ wide, the smaller ones relatively narrower and often entire, esp. when fertile; margin sclerotic, laterally \pm distinctly revolute. Upper pinnules of pinnae little reduced, not confluent. Pinnae and lamina with a terminal, often relatively broad pinnule. Veins immersed to somewhat prominulous beneath, to 4 times furcate. Sori on $(1-)$ 2-6 (-10) vein-ends, single on smaller, entire pinnules, larger pinnules with a sorus to a lobe; indusium rigid, subentire to entire, the sides at least for $\frac{1}{2}$ of their length attached, ca. $1 \mathrm{~mm}$ wide, not quite reaching the margin. Spores medium brown, trilete, subglobose, ca. $30-35 \mu$.

Fig. 3C

Distribution: endemic; apparently frequent.

Ecology: by creeks and torrents and in dry stream-beds; reported by some to have a preference for ferritic soil. From $50-800 \mathrm{~m}$.

\section{Selected citations:}

Vieillard 1554, Kanala ( $P$, lectotype; isotype $\mathrm{K})$; id. ' 1546 ', Yaté ( $\mathrm{P}$, paratype; B); id. '1546', Unia R. (P, L); id. '1546', Mt. Dore (B, GH, L); Schlechter 15192, Ngoye (B, BO, GH, HBG, K, L, P, Z); Franc ' 540 ', Dumbea R. (B, BRI, P, US); id. '540', Dzumac (B, GH, MICH, P); id. '540', Baie du Sud (BRI, Z); Le Rat 82, Mt. Dzumac (BO, P); Sarasin 161, Ngoy Valley (P, Z); Rohrdorf 157, Baie du Sud (Z); McKee 1086, Mt. Dore (K, U); id. 2057, Plaine des Lacs (U).

A clear-cut species, probably related to Sph. retusa (Cav.) Maxon which occurs in eastern Malesia, east to the Solomon Islands. The terminal pinnules are quite distinctive. 
4. Sphenomeris deltoidea (C. Chr.) Copeland, Univ. Calif. Publ. Bot. 14: 366, 1929. Basionym: Lindsaea deltoidea C. Christensen, Ind. Fil. 393, 1906, based on: Lindsaea elongata Labillardière, Sert. Austro-Caled. 6, t. 9, 1824, non Cavanilles, 1802. - Schizoloma elongatum (Lab.) Kuhn, Chaetopt. 346, 1882. - Stenoloma deltoideum (C. Chr.) C. Chr., Ind. Fil. Suppl. III: 173, 1934. - Type: Labillardière s.n., New Caledonia (P!).

Rhizome rather long-creeping, with an internal sclerotic strand, in adult plants stout, $7 \mathrm{~mm}$ in diam.; smaller, not full-grown plants which are often fertile with much thinner rhizome. Scales castaneous, tot $4 \mathrm{~mm}$ long, with 3-4 rows of cells at the base, with a long apical part of 1 row of cells. Petioles rather remote, fawn-coloured, abaxially terete, stout, 3-6 mm thick, 15-45 cm long, about as long as the lamina. Lamina ovate or deltoid, $1 \frac{1}{2}-2 \times$ as long as broad, subcoriaceous or coriaceous, usually drying brown, bipinnate + pinnatifid or tripinnate; primary rachis somewhat flexuous. Pinnae to ca. 10 to a side, ovate to rhombic-deltoid, petiolulate, acuminate, the lower ones sometimes remote, the upper ones gradually and strongly reduced, no conform terminal pinna present. Pinnules rather remote, narrowly rhombic-deltoid, acuminate or acute, in larger pinnae 7-10 to a side, the upper ones gradually and strongly reduced, confluent; pinnules of larger pinnae pinnatifid or pinnate at base, with rhombic or ovate-oblong, pinnatilobate secondary pinnules up to ca. $1 \frac{1}{2} \mathrm{~cm}$ long and $1 \mathrm{~cm}$ wide; upper part of pinnules always pinnatifid, with upward gradually reduced segments. Margin often sclerotic and then somewhat revolute. Veins somewhat prominulous or immersed but evident, $2-3 \times$ forked in the larger lobes. Ultimate lobes truncate, slightly narrowed to apex or almost parallel-sided, the larger ones 3-5 $\mathrm{mm}$ wide at apex, the sinuses between them narrow, acute. Sori mostly borne on all vein-ends of a lobe, on larger lobes 4-8-nerval, also borne on smaller lobes and sometimes extending nearly or quite to the apices of pinnae and pinnules. Indusium rigid, subentire, pale to medium brown, ca. $\frac{1}{2} \mathrm{~mm}$ wide, almost reaching the margin but reflexed at full maturity. Spores pale brown, trilete, smooth, ca. 38-45 $\mu$. (For an illustration of a sporangium, see Kramer, 1957, p. 120, fig. 18).

Fig. 3B

Distribution: New Ireland, Solomon Islands; New Hebrides?

Ecology: in thickets and moist, open places, often by watercourses, 50-300 m; often on ferritic soil. Apparently common.

\section{Selected citations:}

Labillardière s.n.s.l. (P, type; isotype B); Vieillard ' 1545 ', Wagap (B, L, P); id. '1545', Unia (GH, K, P); Schlechter 14815, Yaouhé (B, HBG, K, L, P, Z); Sarasin 13, Oubatche (P, Z); Buchholz 1051, Mt. Dore (K, US); Rohrdorf 185, Baie du Sud (Z); Franc ' 358 ', Mt. Koghi (BRI, K, L, MICH, P, US, Z); id. '358', L'Hermitage (B, K, L, P, Pic.-Ser., U); id. '358', Plum (B, BRI, K, L, SING); McKee 4652, road to Montagne des Sources (U, US); C. Moore 3, Kanala $(\mathrm{K})$; Däniker 1580, island Yandé (Z). Isle of Pines: Vieillard $164(\mathrm{P})$; Milne $206(\mathrm{~K})$; McGillivray $33(\mathrm{~K})$; id. 747 (GH, K); Germain s.n. (B, K, P). 
The closest relative of this distinctive species is probably $S p h$. retusa (see under the preceding species).

\section{Lindsaea Dryander}

Artificial key to the species:

1. Veins anastomosing, sometimes free in smaller lobes . . . . . . . 2

- Veins quite free . . . . . . . . . . . . . .... 4

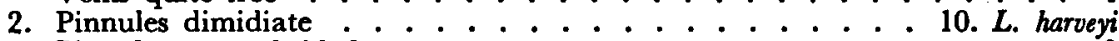

- Pinnulest equal-sided . . . . . . . . . . . . . 3

3. Sterile margin coarsely serrato-dentate; sori strongly intramarginal . . . . . . . . . . . . . . . . . . . . . 6. L. vieillardii

- Sterile margin crenate to subentire; indusium almost or quite reaching the margin (except when reflexed) . . . . . . . . . 5. L. ensifolia

4. Lamina simply pinnate; shorter, spreading, sterile leaves always present beside the erect fertile ones, their pinnules sometimes incised . . . . 5

- Lamina bipinnate or more dissected; full-grown plants without sterile leaves, or these not appreciably different from the fertile ones . . . . . . 6

5. Axes dark; pinnules of sterile leaves sinuate . . . . . . 8. L. linearis

- Axes pale; pinnules of sterile leaves cleft . . . . . . . . 7. L. dimorpha

6. Upper pinnules strongly reduced, confluent to the pinna-apex; sori short, uni- or binerval ... . . . . . . . . . . . . 7

- Upper pinnules not strongly reduced, a large, free or almost free terminal pinnule (segment) present; fully fertile pinnules with longer sori . . . . 8

7. Lamina with a conform terminal pinna; pinnules dimidiate; spores trilete . . . . . . . . . . . . . . . . 9. L. francii - Lamina without a conform terminal pinna; pinnules (ultimate segments) not dimidiate; spores monolete. . . . . . . . . . . . . . . 1. L. moorei

8. Terminal pinnule linear, coarsely serrate; leaf-tissue herbaceous; veins immersed; sori strongly interrupted, the larger ones occupying the outer and part of the lateral margin of the pinnule-lobes, with very concave base

. . . . * . . . . . . . . . . .4. L. prolongata

- Terminal pinnule triangular to ovate-lanceolate, crenate, or serrate at base only; leaf-tissue subcoriaceous to coriaceous, with prominulous veins; sori long, little interrupted, or, if short, occupying only the outer margin

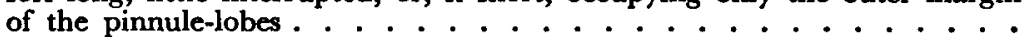

9. Terminal pinnule (segment) acute or acuminate; very few (or no) transitions at base of terminal pinna from pinnate lateral pinnae to lobed basal pinnules of terminal pinna, i.e., lamina almost (or quite) with a conform terminal pinna. . . . . . . . . . . . . 3. L. nervosa

- Terminal segment obtuse; several transitions near lamina-apex from pinnate pinnae through very asymmetrically divided or basally asymmetrical pinnules to simple ones, i.e., no distinct, conform terminal pinna present . . . . . . . . . . . . . . 2. L. rufa

Section Davalliastrum (Fournier) Kramer, stat. nov. - Lindsaea (subdivision, without indication of rank; best regarded as subgenus) Davalliastrum Fournier, Ann. Sci. Nat. V. 18: 330, 1873. Lectotype species: Lindsaea moorei (Hooker) Fournier.

Fournier's characterization of this group is so brief, 'fronde decomposita', that its validity may be doubted. It also comprises species of what I regard as two genera, Lindsaea and Sphenomeris, and in the former of two sections, Schizoloma and Davalliastrum. Yet 6 of the 10 species belong to the group as defined here, although I regard them as forms of a single species. 
Rhizome terrestrial, with a Lindsaeoid protostele but near the leafbases with an internal sclerotic strand; scales ovate, small, inserted on protuberances of the rhizome cortex (see fig. 5). Lamina decompound, free-veined; sori nearly always uninerval, terminal or subterminal on the lobes of the pinnately incised ultimate free divisions; indusium membranous, only attached at the (often convex) base, laterally free; spores monolete.

I have long hesitated before including this species in Lindsaea. It shows resemblance to Sphenomeris and Tapeinidium, particularly in the leaf-pattern and in the rhizome anatomy. Its laterally free indusia and the shape of its scales exclude it, however, from both genera; it may be related to Sph. angustifolia but is in my opinion closer to the group of species which I united (KRAMER, 1957) in the section Pseudosphenomeris. The insertion of the scales on mounds is unlike anything I have seen in Lindsaea; and monolete spores, not uncommon in the neotropical species, are very rare in the paleotropical ones. The solution to erect a new genus for it seems to have too little support; moreover it is undesirable in a group where the separation of the described genera already meets with difficulties. I therefore prefer to leave it in the most heterogeneous of the Lindsaeoid genera. I cannot agree with Hieronymus (1920) that its closest relative is Tapeinidium denhamii (Hooker) C. Chr.

1. Lindsaea moorei (Hooker) Fournier, Ann. Sci. Nat. V. 18: 336, 1873. Basionym: Davallia moorei Hooker, 2nd Cent. Ferns t. 53, 1861. - Odontosoria moorei (Hooker) Kuhn, Chaetopt. 346, 1882. Tapeinidium moorei (Hooker) Hieronymus, Hedwigia 62: 13, 1920. Sphenomeris moorei (Hooker) Copeland, Univ. Calif. Publ. Bot. 14: 366, 1929. - Type: Ch. Moore 5, Kanala (Ganalla) (K!).

Lindsaea balansae Fournier, Ann. Sci. Nat. V. 18: 335, 1873. - Type: Balansa 1652, Messioncoué (P!).

Lindsaea campylophylla Fournier, Ann. Sci. Nat. V. 18: 335, 1873. Sphenomeris campylophylla (Fournier) Tardieu, Am. Fern Jo. 48: 34, 1958. - Type: Balansa 854, nr. Daaoui de Ero (P!).

Lindsaea exilis Fournier, Ann. Sci. Nat. V. 18: 335, 1873. - Lectotype: Balansa 1650, between Ouailou and Couaoua (P!).

Lindsaea flavicans Mettenius ex Fournier, Ann. Sci. Nat. V. 18: 334, 1873. - Tapeinidium flavncans (Mett. ex Fourn.) Hieronymus, Hedwigia 62: 13, 1920. - Lectotype: McGillivray F 14, Kanala (P!).

Lindsaea mediocris Fournier, Ann. Sci. Nat. V. 18: 336, 1873, - Lectotype: Balansa 42a, Mt. Cougui (Koghi) (P!).

Davallia lenormandi Baker, Syn. Fil. $2^{\text {nd }}$ ed. 471, 1874. - Odontosoria lenormandi (Baker) C. Chr., Ind. Fil. 465, 1906.-Lectotype: Deplanche 1 (herb. Lenormand), N. Cal., without loc. (K!). ${ }^{1}$ )

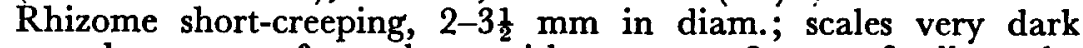
brown, lustrous, to $\frac{2}{3} \mathrm{~mm}$ long, with up to ca. 6 rows of cells at the base, the apical part of one row of cells rather short, apical cell

1) The names $L$. mariae Fourn. and $L$. pancheri Fourn., cited by Gulliaumin (1964), are nomina nuda. 
glandular but often lost. Petioles close, abaxially terete to very obtusely bi-angular, reddish to blackish brown but not rarely the upper part and the adaxial side paler, stramineous or mottled, ca. $15-40 \mathrm{~cm}$ long, in large leaves $1 \frac{1}{2}-3 \times$ as long as the lamina, $1-2 \mathrm{~mm}$ in diam. Lamina very variable, chartaceous to coriaceous, ovate-oblong to subrhombic, triangular, or pentagonal, up to ca. $30 \times 15 \mathrm{~cm}$, bipinnate + pinnatilobate to tripinnate + pinnatipartite, drying pale brownish to dark green but mostly olivaceous. Primary rachis similar to the upper part of the petiole; secondary rachises abaxially terete, pale (sometimes abruptly so), like those of higher order upward increasingly green-margined. Primary pinnae obliquely ascending or the lower ones patent, short-petiolulate to subsessile; major pinnae mostly 3-5 to a side, the upper ones gradually reduced, of simpler structure, confluent into a pinnatifid, often acuminate leaf-apex. Basal pinnae the largest, often, especially in large laminas, strongly basitonically developed, then the outline of the lamina \pm pentagonal. Pinnules and segments decurrent into the wings of the axes; apices of the pinnae (and pinnules in tripinnate leaves) like the apex of the lamina. Ultimate segments very variable, truncate-cuneate, obovatecuneate, subrhombic-cuneate, $2-4 \mathrm{~mm}$ wide, or less often linearcuneate, $1-2 \mathrm{~mm}$ wide, of very variable size depending on the specimen and the place in the lamina; margin not sclerotic, sometimes subrevolute, serrato-pinnatilobate to pinnatifid in larger segments. Veins pinnately branched, abaxially often pale and prominulous. Sori uni- (very rarely bi-) nerval, on the teeth of the ultimate segments, $\frac{1}{2}-1$ (very rarely -2 ) $\mathrm{mm}$ long, $\frac{1}{2} \mathrm{~mm}$ wide; indusium pale to medium brown, free at the sides, erose to cleft, not reaching the margin by less than its width to almost reaching it, not reflexed at maturity. Edge of lamina opposite the indusium not rarely erose or uni- or bicorniculate. Sporangia intermingled with numerous soral trichomes of one row of cells. Spores pale brown, monolete, bean-shaped to ellipsoidal, ca. $60 \times 40 \mu$. (See also the description of the section).

Fig. 1B, 4A

Distribution: endemic (one coll. found as an admixture in a collection from Fiji, but probably not collected there).

Ecology: in open places, crevices of rocks, by watercourses and in forests, on ferritic and serpentine substrate, from c. 100-1050 m. There is probably some connection between the variability of this species and the fact that it is very euryoeceous. The finely dissected plants mostly seem to come from forests, but the ecological data are insufficient for definite conclusions.

Selected citations:

Balansa 1652, Messioncoué ( $\mathrm{P}$, holotype of $L$. balansae; isotypes $\mathrm{P}, 2$ sh., B); id. 854, Daaoui de Ero ( $P$, holotype of $L$. campylophylla; isotype $P$ ); id. 1650 , between Ouailou and Couaoua ( $P$, lectotype of $L$. exilis; isotypes $P, 2$ sh.); id. 42a, Mt. Koghi (P, lectotype of $L$. mediocris; isotypes $P, B)$; Balansa 165 la, Prony (P, paratype of $L$. mediocris); Ch. Moore 5, Kanala (type, K); McGillivray F 14, Kanala (P, lectotype of $L$. flavicans); McKee 4690, Montagne des Sources (K, L, U, US); 
id. 3534, Mt. Mou (P, U); Franc ' 360 ', Koghi (BRI, K, L, MICH, P, Pic.-Ser., US); id. ' 360 ', Mt. Dore (BRI, K, P, Z); Vieillard 1548 and 1549 , Wagap (B, P); Sarasin 589, Yaté (P, Z); Schlechter 15046, Yaouhé (B, HBG, K, P, Z); id. 15344, Ngoye (Z), 15364, ibid. (B, K, P); id. 14955, Paita (B, K, L, P, Z); Guillaumin 10920, Rivière Bleue (Z); Virot 586, Plaine des Lacs (A). Isle of Pines: Pancher s.n. (B, K, P, paratypes of $L$. flavicans.).

BrownLIE (1961) already emphasized the great variability of this species. With an ample series of material at hand, notably in the Paris herbarium, I am unable to find any reliable distinction between the, admittedly rather divergent, forms described as species by Fournier (1873). Brownlie (l.c.) referred L. tenuifolia Mettenius to this species, but it is a synonym of Sphenomeris chinensis (q.v.).

Section Schizoloma (Gaud.) Kramer, stat. nov. - Schizoloma Gaudichaud, Ann. Sci. Nat. 3: 507, 1824 (as genus). - Lindsaea subgenus Schizoloma (Gaud.) Hooker, Spec. Fil. I: 219, 1844; Kramer, Acta Bot. Neerl. 6: 271, 1957.-Lindsaea section Pseudosphenomeris Kramer, l.c., p. 165 .

2. Lindsaea rufa Kramer, spec. nova. - Schizoloma heterophyllum (Dryander) J. Smith forma major 'Fournier'; C. Christensen, Beibl. Vierteljahrsschr. Naturf. Ges. Zürich 77: 20, 1932, based on $L$. heterophylla Dryander forma major Fournier, l.c., p. 331, 1873, which is in my opinion not intended as a formal description of a new forma but a critical note on the specimens.

Rhizoma breviter repens, $2 \mathrm{~mm}$ crassum, squamis angustis ferrugineis obtectum; petioli approximati, abaxialiter bi-angulares, rufescentes vel deinde brunnescentes. Lamina petiolo brevior, subcoriacea, bipinnata, pinnis pinnulisque obtusis, pinnulis superioribus sensim abbreviatis, pinnam terminalem lateralo-basalibus similem non efformantibus. Venae liberae, prominulae. Margo scleroticus, crenatus, incisionibus soros plerumque hinc inde interrumpentibus. Indusium rigidum, marginem non attingens.

Additional characters: scales lanceolate acuminate, up to $2 \mathrm{~mm}$ long, with up to 8 rows of cells at the base. Petioles ca. $12-35 \mathrm{~cm}$ long, about twice as long as the lamina, $1-1 \frac{1}{2} \mathrm{~mm}$ in diam., dull; rachis similar to the petiole, secondary rachises paler, abaxially subterete. Lamina rarely subtripinnate, ovate or oblong, $1 \frac{1}{2}-2 \times$ as long as wide, drying olivaceous-brown; pinnate pinnae in about 4 pairs, about as many lobed or simple ones above, progressively shorter from base to apex of lamina, the upper ones obovate-flabellate, ca. $1 \mathrm{~cm}$ long, scarcely confluent with the asymmetrically lanceolate terminal pinnule; pinnules of pinnate lateral pinnae $1-3$ to a side, similar to the ones near the leaf-apex or the lower, largest ones more elongate. Costae soon evanescing in flabellate, more pronouncedly developed in lanceolate pinnae (pinnules); veins mostly twice forked. Margin stramineous or reddish, lobes subacute in sterile pinnules, flattish and separated by incisions up to ca. $1 \mathrm{~mm}$ deep in fertile pinnules. Sori usually occupying all vein-ends of fully fertile pinnules, 
continuous in small, interrupted by the crenations in larger pinnules, there the longest ca. $1 \mathrm{~cm}$ long. Indusium stramineous. subentire, ca. $0.3-0.4 \mathrm{~mm}$ wide, falling short of the margin approximately by an equal distance, \pm reflected at maturity. Spores pale brown, slightly tuberculate, trilete, ca. $27 \mu$.

Fig. 2C, 3D

Type: Schlechter 15108, Ngoye (B).

Distribution: endemic.

Ecology: in forests, 100-1250 m (few data).

Specimens seen:

Franc 2039 p.p., s.loc. (MICH); id. 1393 p.p., Mt. Mou (BRI, K, MICH); Balansa 1602a, Mt. Humbold (P); Skottsberg 55, Montagne des Sources (S-PA); Vieillard 3354, Mt. Mou (B); Schlechter 15108, Ngoye (B, holotype; isotypes B, $\mathrm{BM}, \mathrm{BO}, \mathrm{GH}, \mathrm{HBG}, \mathrm{K}, \mathrm{L}, \mathrm{Z})$.

The sclerotic margin, the firm texture, and the free veins distinguish this species readily from $L$. heterophylla with which it has been confused and which may be its closest relative. It may be even closer to $L$. nervosa; for the differences see the key.

3. Lindsaea nervosa Mettenius, Ann. Sci. Nat. IV. 15: 62, 1861, non Lindman, 1903. - Schizoloma nervosum (Mett.) Kuhn, Chaetopt. 346, 1886. - Type: Vieillard 1540, Mont Dore (P!).

Lindsaea macgillivrayi Carruthers ex Seemann, Fl. Vit. 337, 1873. Type: McGillivray F 16, 'interior of New Caledonia' (BM!).

Lindsaea neocaledonica Compton, Jo. Linn. Soc. 45: 443, 1922. - Type: Compton 791, Mt. Koghi (BM!).

Rhizome rather short- to long-creeping, $1 \frac{1}{2}-2 \mathrm{~mm}$ in diam.; scales rufous, narrow, to $2 \mathrm{~mm}$ long, with up to 3 rows of cells at the base and a long apical part of one row. Petioles close to remote, ca. 20-50 cm long, mostly exceeding the lamina, reddish brown (mostly dark), \pm shining, abaxially terete or bi-angular upward, 1-2 $\mathrm{mm}$ in diam. Lamina subcoriaceous, or occasionally chartaceous or coriaceous, drying olivaceous to dark green, $15-40 \mathrm{~cm}$ long, $15-25 \mathrm{~cm}$ broad, oblong or in small leaves as broad as long, bipinnate or rarely subtripinnate, with 3-11 pinnae to a side and an almost or quite conform terminal one; primary rachis similar to the petiole, secondary rachises reddish brown, abaxially terete. Pinnae patent or obliquely ascending, subsessile to short-petiolulate, linear; upper pinnae, esp. in large leaves, somewhat or occasionally strongly shortened; larger pinnae commonly $10-15 \times 2 \mathrm{~cm}$, with ca. 20 pinnules to a side, rarely the basal pinnae with a basal basiscopic pinnate secondary pinna. Pinnules of variable shape but distinctly dimidiate: semi-elliptic or subovate and very obtuse to rhombic or caudato-acuminate. Basal pinnules scarcely or not, upper pinnules little reduced, none or 1 or 2 connected with the asymmetrically lanceolate or hastate, acute or acuminate, often pinnately lobed terminal pinnule (segment). Terminal pinna at base mostly with some enlarged, lobed pinnules forming a vestigial transition to the upper pinnae. Margin of pinnules 

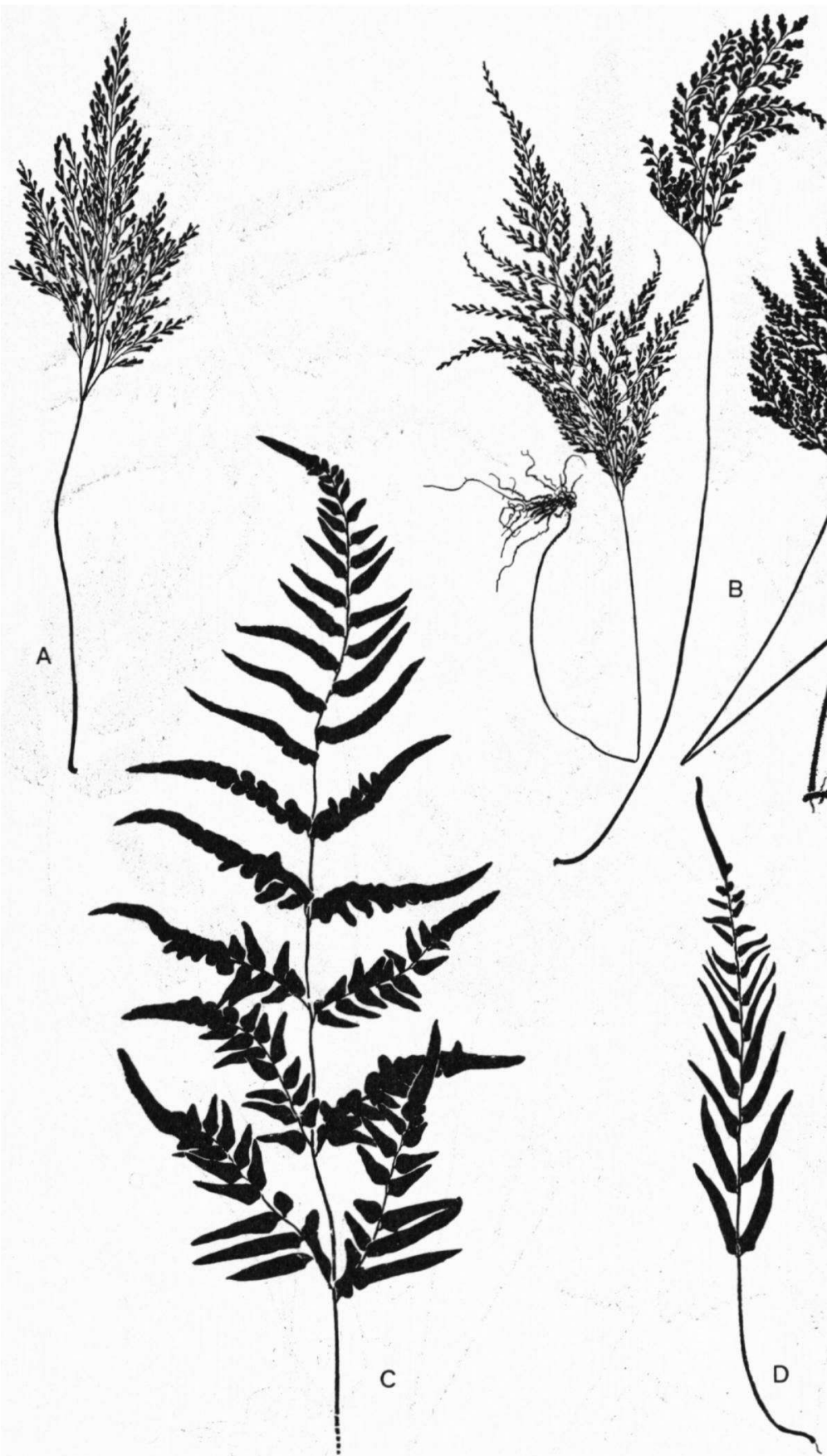
K. U. KRAMER

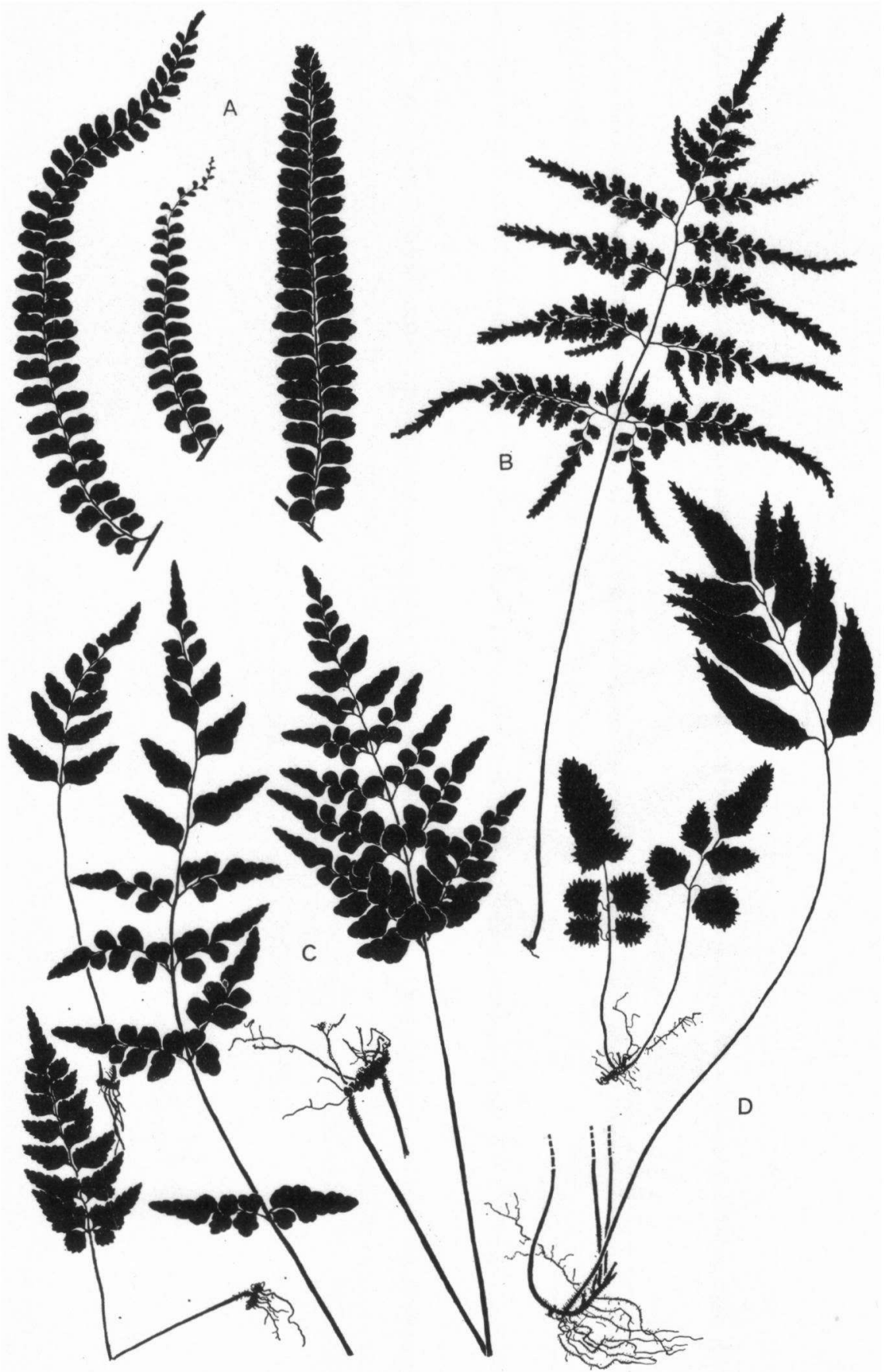

Fig. 2. A: Lindsaea nervosa, pinnae from three different plants. B: Lindsaea prolongata. C: Lindsaea rufa, two leaves of juvenile plants (left) and two of adult plants (centre, right). D: Lindsaea vieillardii, juvenile and adult plant. 


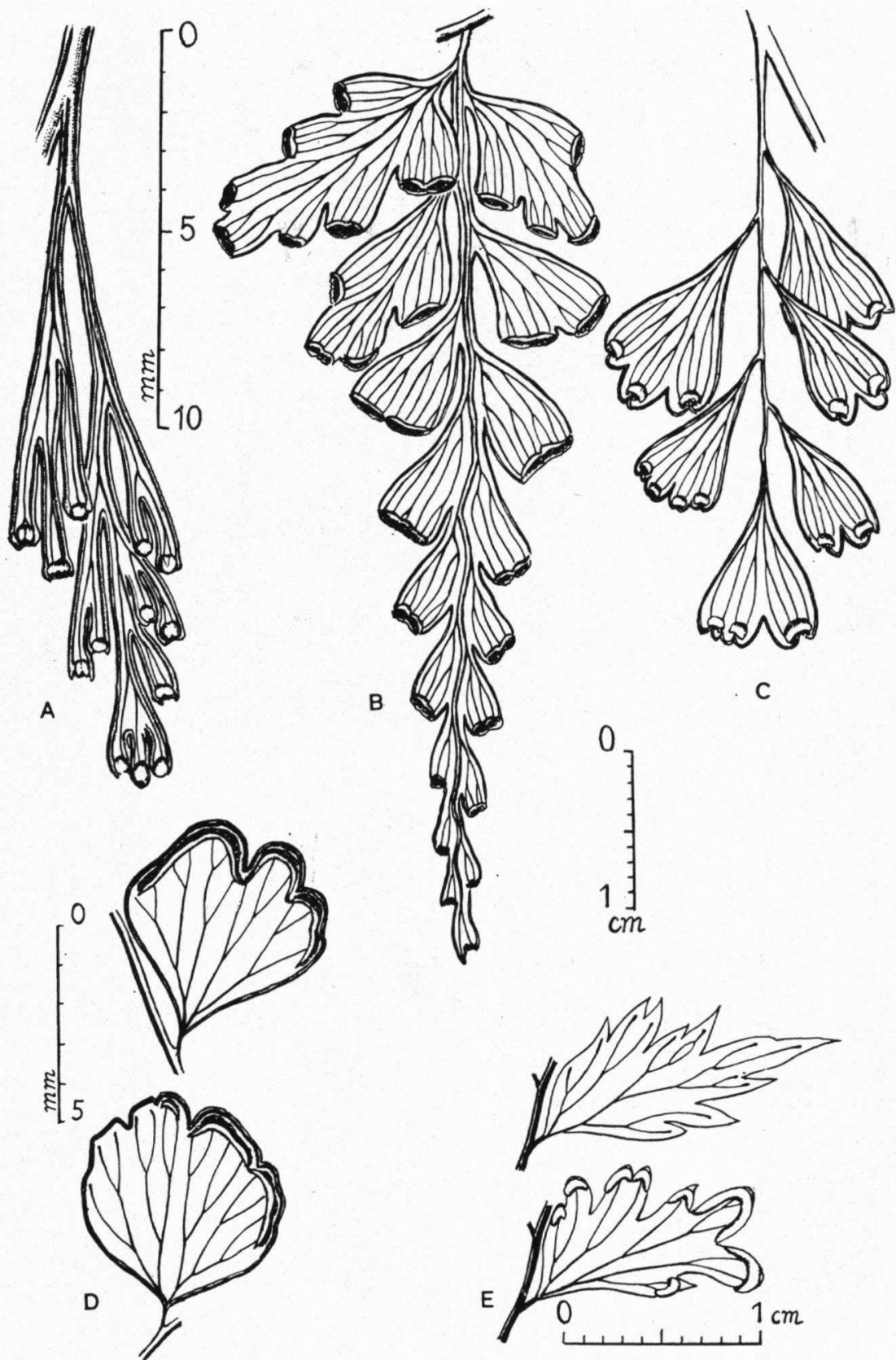

Fig. 3. A: Sphenomeris angustifolia, a pinnule. B: Sphenomeris deltoidea, a sec. pinna. C: Sphenomeris alutacea, a pinna. D: Lindsaea rufa, two pinnules. E: Lindsaea prolongata, a sterile and a fertile pinnule. 


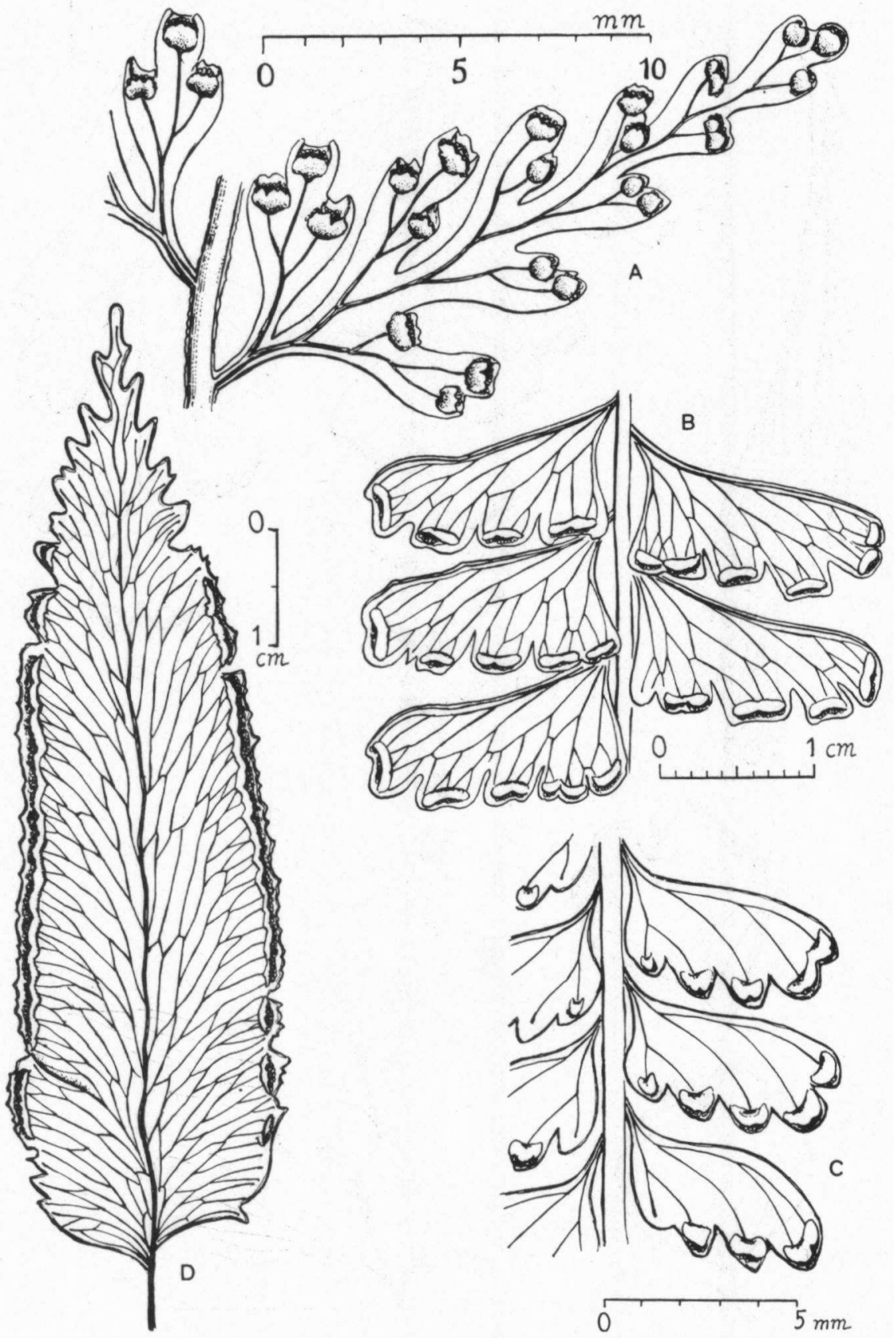

Fig. 4. A: Lindsaea moorei, an average upper pinna. B: Lindsaea harveyi, larger pinnules. G: Lindsaea francii, idem. D: Lindsaea vieillardii, a large pinna. 


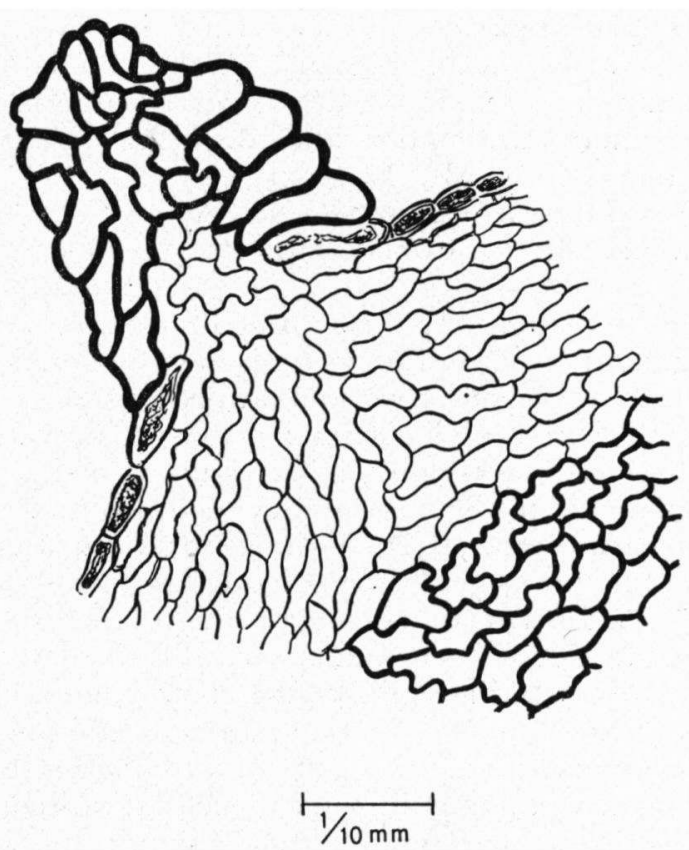

Fig. 5. Lindsaea moorei (McKee 5524), part of cross-section of rhizome showing insertion of scale.

sclerotic, stramineous, sometimes erose, entire to incised, the incisions few, usually 1 on the outer and 2 on the upper margin, rarely up to $2 \mathrm{~mm}$ deep; sterile pinnules regularly crenato-dentate. Veins elevated, pale, mostly twice forked, free. Sori continuous, or interrupted in incised pinnules, then often 4-6-nerval. Indusium pale, rigid, erose to subentire, ca. $\frac{1}{4}-\frac{1}{3} \mathrm{~mm}$ wide, not reaching the margin by an equal distance or less, reflexed at maturity. Spores pale brown, smooth, trilete, ca. $25 \mu$.

Fig. 2A

Distribution: endemic.

Ecology: in rocky forests, in moist places, sometimes by watercourses, on ferritic and serpentine soil, $300-850 \mathrm{~m}$. Apparently not rare.

Selected citations:

Franc '363' Koghi (MICH, US); id. '363', Mt. Dzumac (B, K, L, P); id. '1467', Mt. Dore (GH, Pic.-Ser.); id. '679', Baie du Sud (BRI, K, P); Vieillard '1540', Mt. Dore (P, type; isotype B); id. ' 1540 ' p.p., Wagap (B, L, P); Balansa 2694, Mt. Mou (B, BM, K, P, U); Däniker 322, Plaine des Lacs (Z); Sarasin 621, Yaté (P, Z); Buchholz 1260, Montagne des Sources (BISH); Compton 990, Mt. Nekando (BM); id. 791, Koghi (BM, type of L. neocaledonica); McKee 2617, Yaté Road (BM, GH, U).

The great variability in the shape of the pinnules of this species is mainly due to the influence of the degree of fertility. 
4. Lindsaea prolongata Fournier, Ann. Sci. Nat. V. 18: 334, 1873. - Schizoloma prolongatum (Fournier) Kuhn, Chaetopt. 346, 1882; Brownlie, Pacific Science 15: 65, 1961, comb. superf. - Schizolegnia prolongata (Fournier) Alston, Bol. Soc. Brot. 2a sér. 30: 24, 1956. Lectotype: Balansa 1602. Mt. Arago (P!).

Lindsaea cheiroides Fournier, Ann. Sci. Nat. V. 18: 334, 1873. - Lectotype: Balansa 827, nr. La Conception (P!).

Rhizome short-creeping, $1 \frac{1}{2}-2 \mathrm{~mm}$ in diam.; scales medium brònn, narrowly triangular, to $2 \mathrm{~mm}$ long, with up to 5 rows of cells at the base, the apical part of one row comparatively short. Petioles close, dull, medium to dark brown, abaxially at least upward bi-angular, $15-40 \mathrm{~cm}$ long, $1 \frac{1}{2}-2 \times$ as long as the lamina, $1-1 \frac{1}{2} \mathrm{~mm}$ in diam. Lamina bipinnate or (in the basal pinnae) subtripinnate, herbaceous, mostly drying dark green, $10-20 \mathrm{~cm}$ long, to $15 \mathrm{~cm}$ wide, triangularsubpentagonal or in large leaves oblong, with 2-7 pinnae to a side and a \pm conform terminal one; primary rachis similar to the upper part of the petiole, secondary rachises abaxially obtusely biangular or terete, reddish to dark, the dark colour ending in the cuneate bases of the pinnules. Pinnae patent or obliquely ascending, mostly long-acuminate, narrowly oblong to linear, the basal ones longest, the lower ones sometimes with a basal basiscopic pinnatifid or pinnate, prolongate secondary pinna. Pinnules in outline mostly obliquely elliptic, the larger ones $1 \frac{1}{4}-1 \frac{1}{2} \times \frac{3}{4}-1 \mathrm{~cm}$, unevenly pinnatolobate (to ca. $\frac{1}{3}$ ) on the upper and outer margin, the lobes acute and sometimes lobed again when sterile, rounded or narrowed-rounded when soriferous, then rarely lobed again; incisions in fertile pinnules up to $3 \mathrm{~mm}$ deep, sinuses acute, narrow to broad; some pinnules, especially the basal basiscopic ones, the upper ones, and the basal ones of the terminal pinna, sometimes prolongate-acuminate. Upper pinnules little reduced, none or a few connected with the pinnaapex which is linear-acuminate, serrate throughout or at the base hastato-lobate or pinnatifid, to $6 \mathrm{~cm}$ long, $\frac{2}{3}-1 \mathrm{~cm}$ broad; terminal pinna not rarely with the basal pinnules enlarged, more deeply lobed or even pinnatifid, forming a rudimentary transition from pinnate pinnae to lobed pinnules. Margin of pinnules often stramineous and sometimes sclerotic, often erose at the ends of the lobes. Veins evident, immersed or subprominulous, free, $2-3 \times$ forked, pinnate and once or twice forked in the pinna-apices. Sori occupying the lobes but, except in shallow incisions, interrupted at the bottom of the sinus, on 1-6 vein-ends (entire and longer only in small pinnules), with very concave base, the receptacle laterally extending considerably beyond the vein-ends which bear it. Indusium pale, slightly erose to subentire, $0.3-0.4 \mathrm{~mm}$ wide, mostly not quite reaching the margin. Spores very pale brown, minutely tuberculate, trilete, ca. 22-26 $\mu$.

Fig. 2B, 3E

Distribution: endemic.

Ecology: in forests, $300-500 \mathrm{~m}$. 
Selected citations:

Franc '365', Koghi (B, BO, BRI, K, L, MICH, P, SING, U, US, Z); id. '365', St. Louis (B, BRI, US); Balansa 1602, Mt. Arago ( $P$, type; isotype $K$ ); Vieillard 1540, Wagap (B, BM, GH, K, L, P, Pic.-Ser., U); Balansa 827, La Conception (P, type and isotype of $L$. cheiroides); Le Rat 565, Mt. Mou (B, K); McKee 4439, Koghi (BM, L, US); id. 4955, Thy Valley to Mt. Koghi (BM, US).

BROWNLIE (1961) showed that $L$. prolongata and $L$. cheiroides are conspecific and chose the former name for the combined species. His statement that $L$. prolongata, as understood by Fournier, does not have elongated terminal divisions is disproved by the material in the Paris herbarium, and also by the name chosen by Fournier. $L$. prolongata is closely related to $L$. nervosa; the combination of thin texture, peculiar terminal segments, and sori with very concave base occupying parts of the lateral edges of the lobes identifies it readily.

5. Lindsaea ensifolia Swartz, Schrad. Journ. 1800²: 77 1801. Schizoloma ensifolium (Swartz) J. Smith, Hooker's Jo. Bot. 3: 414, 1841. - Schizolegnia ensifolia (Swartz) Alston, Bol. Soc. Brot. 2a sér. 30: 24, 1956. - Type: unknown collector, Mauritius (S-PA!).

A description and the full synonymy of this well-known species will be given elsewhere, with the reasons why I cannot accept Domin's (1915) subdivision of this species. In New Caledonia there are two subspecies: ssp. ensifolia with scarcely or not abbreviated upper pinnae and a free, conform terminal one, and spp. agatii, with the upper pinnae gradually reduced and confluent with the basally lobed terminal segment. $\quad$ Fig. 1C, D ssp. ensifolia

Distribution: tropical, here and there subtropical parts of the Old World, from West Africa to tropical Australia.

Ecology: open places, rocks, at lower elevation.

New Caledonian specimens seen:

Beaudouin s.n.s. loc. ( $\mathrm{K}, \mathrm{P})$.

ssp. agatii (Brackenridge) Kramer, stat. nov.- Basionym: Schizoloma agatii Brackenridge, U.S. Expl. Exped. 16: 216, t. 30, f. 1, 1854.-Type: U.S. Expl. Exped. s.n. from Fiji (US? not seen; isotype K!).

Distribution: from Timor and New Guinea east to Samoa. Ecology: like ssp. ensifolia.

Selected citations:

Vieillard 1557, Balade (B, K); Schlechter 14740, Yaouhé (B, BM, GH, HBG, K, L. Z); Franc '704', Plum (K, L, SING); id. '704', Baie du Sud (BRI, US); id. '704', Paíta (BRI, Z); id. 704a, N'Go (K, L, P, SING); id. s.n. (Rosenstockexs. 137), Baie des Pirogues (B, GH, L, MICH, US); McKee 2538, Hienghène (BM, K, U, US). 
In some areas the two subspecies occur together, e.g. in Guam, New Guinea, tropical Australia, and New Caledonia. Intermediates are sometimes found there, notably in New Guinea and Australia. L. ensifolia ssp. agatii is often much like $L$. heterophylla Dryander; this is particularly true for a bipinnate form which occurs in New Guinea, Ponape, New Caledonia, and Australia; there are some subbipinnate intermediates. $L$. heterophylla has less regularly anastomosing veins, and the pinnules, notably the upper ones, are relatively wider. Its easternmost stations are in Borneo and the Philippines.

6. Lindsaea vieillardii Mettenius, Ann. Sci. Nat. IV. 15: 65, 1861. - Schizoloma vieillardii (Mett.) Kuhn, Chaetopt. 346, 1882. Schizolegnia vieillardii (Mett.) Alston, Bol. Soc. Brot. 2a sér. 30: 24, 1956. - Type: Vieillard 1566, Balade (P!).

Lindsaea vieillardii Mett. var. serrata Compton, Jo. Iinn. Soc. 45: 444, 1922. - Type: Compton 1765, Mt. Panié (BM!).

Rhizome rather short-creeping, $1 \frac{1}{2}-2 \mathrm{~mm}$ in diam.; scales medium brown, almost acicular, to $1 \frac{1}{2} \mathrm{~mm}$ long, with up to 3 rows of cells at the base, about half of the scale of one row of cells only. Petioles rather close, atropurpureous to blackish, abaxially at least in the upper part bi-angular, ca. 10-25 cm long, exceeding the lamina, slender, $\frac{2}{3}-1 \mathrm{~mm}$ in diam. Rachis dark, the dark colour evanescing in the petiolules or occasionally in the basal part of the costae. Lamina herbaceous, drying dark green, simply pinnate, with 1-5 pairs of subopposite pinnae and a \pm conform terminal one; pinnae petiolulate (to $\mathrm{ca} .1 \mathrm{~cm}$, the terminal one to $2 \mathrm{~cm}$ ), or the upper ones subsessile; larger pinnae ligular, obtuse to acute, with obtuse or truncate base, up to $7 \mathrm{~cm}$ long and $2 \mathrm{~cm}$ wide, $3-7 \times$ as long as wide; smaller pinnae and pinnae of young plants often ovate and much shorter. Lateral pinnae often upcurved and asymmetric; terminal pinna \pm symmetric, rarely lobed at base. Costa approximately median, percurrent in the lower pinnae, slightly prominent beneath, mostly pale to base; veins immersed but evident, very oblique at the costa, arching to meet the margin nearly at right angles, the primary branches issuing from the costa at distances of about $5 \mathrm{~mm}$, regularly reticulate, forming a series of low, long costal areoles and 1 or 2 partly overlapping series of progressively shorter ones or sometimes veins free from the costal areoles to the receptacle, in sterile pinnae their ends clavate and joined or free, ending well within the margin. Margin not thickened, grossly and very irregularly gashed, especially in sterile or incompletely fertile pinnae, with subobtuse, rather broad sinuses; completely fertile pinnae with an erose-sinuate or denticulate margin but nearly always with some deeper incisions as well (to $2 \mathrm{~mm}$ ) that interrupt the sorus, these especially present toward the apex; teeth subacute or acute. Sori uniting several vein-ends, rarely all of a pinna, even around the apex, but mostly progressively more interrupted toward the apex of the pinna. Indusium \pm sinuate, 
ca. $0.3 \mathrm{~mm}$ wide, strongly intramarginal, not reaching the margin by ca. $1 \mathrm{~mm}, \pm$ reflexed at maturity. Spores pale brown, smooth, trilete, ca. $22-\overline{25} \mu$.

Fig. 4D

Distribution: endemic.

Ecology: in shady forests, $350-800 \mathrm{~m}$, apparently uncommon.

Selected citations:

Vieillard '1566', Balade ( $P$, holotype; isotypes $P, 5$ sheets, B); id. '1566', Wagap (BM, GH, K, L, Pic.-Ser.); Franc 1367, Mt. Koghi (BO, BRI, K, L, MICH, Pic.-Ser., SING, US, Z); Schlechter 15042, Yaouhé (B, BM, GH, HBG, K, L, Z); Compton 1765, Mt. Panié (BM, type of var. serrata); Sarasin 313, Kanala (Z); McKee 5304, Chapeau Gendarme to Mt. Koghi (U).

Section Paralindsaea (Keyserling) C. Chr. (See Kramer, 1957, p. 266).

7. Lindsaea dimorpha Bailey, Handb. Queensland Ferns 19, 1874, based on: Lindsaea heterophylla Prentice, Jo. Bot. 11: 295, 1873, non Dryander, 1797. - Type (not cited): Australia, without loc., Bailey s.n. (K!).

Lindsaea anogrammoides C. Christensen, Vierteljahrsschr. Naturf. Ges. Zürich 70: 223, 1925. - Type: Franc 1308, Conception (BM, herb. C. Christensen!).

Lindsaea minima Copeland, Univ. Calif. Publ. Bot. 14: 365, 1929, ex char. - Type Franc 2217, N. Cal., s. loc.? (MICH, not seen). This rare species will be described in the account of the Australian species.

Distribution: n. e. Australia.

Ecology: one record 'cliffs 2000.' Apparently very rare in New Caledonia.

Specimen seen:

J. Roberts s.n., s.loc., Sept. 1886 (K).

Brownlie (1961) pointed out the identity of $L$. dimorpha and $L$. anogrammoides; Christensen (Ind. Fil. Suppl. III: 122, 1934) cited L. minima as a synonym of the last-named species.

8. Lindsaea linearis Swartz, Schrad. Journ. 18002: 78, 1801. Adiantum lineare (Swartz) Poiret, Encycl. Suppl. I: 139, 1810. - Type: presumably from Australia (not stated; not seen).

A description of this well-known species, common in Australia and parts of New Zealand, will be given elsewhere, with the full synonymy.

Ecology: open places, on ferritic and serpentine soil, ca. 600-1000 m; data few. Apparently very localized in New Caledonia. 
Specimens seen:

Deplanche s.n., Mt. Mou (K); id. 140, Mt. Mu (= Mou?) (B); Däniker 817, 817a, Mt. Mou (Z); Franc 1309, ibid. (BRI, K, P); Pancher s.n., ibid. (P); Balansa 2735 , ibid. (P); id. 57, near Nouméa (P); Schlechter 14754, Yaouhé (B, HBG, K, P); Vieillard 1556, Fort de France (P); Le Rat 81, Mt. Mou (P).

Section Temnolindsaea Kramer, Acta Bot. Neerl. 6: 176, 1957. This section, described for neotropical species, by definition comprises a small group of Old World, mainly Malesian, species. It is, however, quite possible that these are more closely related to the section Synaphlebium than to the American species.

9. Lindsaea francii Rosenstock, Fedde Rep. 9: 73, 1910. - Type: Franc 1420, Mt. Tao (P!).

The following description is confined to the main features and the points omitted or incorrectly described by Rosenstock.

Rhizome short-creeping, knotted, 3-5 mm thick; scales dark brown, narrowly triangular, to $2 \mathrm{~mm}$ (or more?) long, with up to ca. 7 rows of cells at the base. Petioles clustered, stramineous to pale brown, smooth, quadrangular and quadrisulcate, ca. $2 \mathrm{~mm}$ thick, to $50 \mathrm{~cm}$ long, exceeding the lamina. Lamina bipinnate, oblong; rachis abaxially bi-angular, sulcate. Pinnae spreading or somewhat ascending, 12-15 to a side and a conform terminal one; upper and lower pinnae slightly shortened, the middle ones ca. $12 \mathrm{~cm}$ long, $12 \mathrm{~mm}$ wide, linear, acuminate; secondary rachises abaxially bi-angular, scarcely sulcate. Pinnules herbaceous, closely and regularly set, $40-50$ to a side, the basal ones slightly, the upper ones strongly reduced and confluent into a pinnatifid pinna-apex; larger pinnules asymmetrically ovate, $6 \times 2 \frac{1}{2}$ $\mathrm{mm}$, the upper margin with 3 , the outer with 1 incision, the incisions oblique, up to ca. $1 \mathrm{~mm}$; lobes mostly subacute or acute. Veins immersed, evident, one running to each lobe. Sori uni- or occasionally the outer one binerval; receptacle on the same level as the sinus; indusium pale, subentire or gashed, often with concave base, not reaching the margin by less than its width but often the sides of the lobes, $\frac{1}{2} \mathrm{~mm}$ wide. Spores very pale, smooth, trilete, ca. $22 \mu$. Fig. 4C

Distribution: only known from type collection (see above; holotype $\mathrm{P}$, isotypes $\mathrm{P}, 2$ sheets; $\mathrm{U}$; fragm. US).

Ecology: in forest, clay soil, $600 \mathrm{~m}$.

Rosenstock (1.c.) compared this species with $L$. davallioides Bl. and Davallia (Lindsaea) delicatula Christ, particularly with the latter. It is not closely related to either one but resembles most closely $L$. kingii Copeland, described a year after $L$. francii.

Section Synaphlebium (J. Smith) Diels in Engler und Prantl, Nat. Pfl. I4: 221, 1902. - Synaphlebium J. Smith, Jo. Bot. 3: 415, 1841, as genus. 
10. Lindsaea harveyi Carruthers ex Seemann, Fl. Vit. 338, 1873. - L. decomposita auctt. plur. poster., non Willd.; L. cultrata auct. non (Willd.) Swartz; Fournier, 1.c., p. 333; L. gracilis auct. non Blume; Fournier, 1.c., p. 333. - Lectotype: Harvey s.n., Fiji (K!).

Recent authors, e.g. Copeland (1929a), included $L$. harveyi in $L$. decomposita Willd. This species which must be properly called L. cultrata (Willd.) Swartz has usually been construed far too widely; it occurs almost exclusively in Malesia. $L$. harveyi is much closer to L. obtusa J. Smith in Hooker, another chiefly Malesian species that is usually included in $L$. 'decomposita'. $L$. harveyi and $L$. obtusa can sometimes be distinguished only with difficulty, especially juvenile and depauperate plants; they should perhaps be treated as subspecies. A description will be given in the account of the species of the smaller Pacific islands. The New Caledonian specimens are nearly all simply pinnate and apparently much less well developed than most collections from Melanesia and Polynesia. This makes the identification less certain, as in the section Synaphlebium generally incomplete or depauperate specimens often cannot be named with certainty. Fig. 4B

Distribution: Solomon Islands to Samoa and Tonga.

Ecology: in forests, by streams, $100-400 \mathrm{~m}$; very few data.

Selected citations:

Franc 1432, Mt. Tao (P, S-PA); Vieillard '1553', Wagap (B, L, P, Pic.-Ser.); id. '1553', Balade (P, U); Balansa 1601, Baie St. Louis nr. Nouméa (P); Cribs 1057, Forêt de Bâ $(\mathbf{K}, \mathbf{P})$.

\section{EXCLUDED SPECIES}

Lindsaea cultrata Swartz. - See note under L. harveyi Carr. ex Seem.

Lindsaea gracilis Blume. - Idem.

Lindsaea heterophylla Dryander. - See under L. ensifolia Swartz and L. rufa Kramer.

Lindsaea microphylla Swartz. - FournIER (1873), p. 336, cited a specimen he had not seen from New Caledonia. There is one in the Paris herbarium marked in Nova Caledonia leg. Ch. Vieillard et Plancher' ... Cl. Lenormand donavit 1857.' The species has never again been found there, and its occurrence, though certainly not impossible considering the presence of other Australian species, is at present very doubtful.

Lindsaea tetragona Kramer. - A specimen belonging to this species, to be described shortly, in the Kew herbarium is marked 'New Caledonia, Macleay:' The species extends to Tahiti but has never been re-collected in New Caledonia, nor in the New Hebrides.

Sphenomeris retusa (Cav.) Maxon. - The specimens cited by Fournier (1873), p. 337 (as Lindsaea retusa Mett.) belong to Sphenomeris chinensis. A specimen in the Paris herbarium collected by Labillardière is Sph. retusa, but its occurrence in New Caledonia seems doubtful as there are no later collections.

Tapeinidium denhamii (Hooker) C. Chr. - Strange s.n. $(K)$ is labelled 'New Cialedonia' and a collection without further data (B, K) 'Isle of Pines'. I suppose the plants came from the New Hebrides or other parts of Melanesia. 


\section{REFERENCES}

Balgooy, M. M. J. van. 1960. Preliminary plant-geographical analysis of the Pacific. Blumea 10: 385.

Brownlre, G. 1961. Studies on Pacific ferns, part III. The Lindsaeoid ferns. Pacific Science 15: 64. 1965. The geographical affinities of the South Pacific Island Fern Floras. Ibid. 19: 219.

Christ, H. 1910. Die Geographie der Farne. Jena.

Christensen, C. 1932. Pteridophyten, in: A. U. Daeniker, Ergebnisse der Reise von Dr. A. U. Däniker nach Neu-Caledonien und den Loyalty-Inseln $(1924 / 6)$. 4. Katalog der Pteridophyta und Embryophyta siphonogama. Beibl. Vierteljahrsschr. Naturf. Ges. Zürich 19 (Jahrg. 77): 8.

Copeland, E. B. 1929a. Ferns of Fiji. B. P. Bishop Mus. Bull. 59: 1.

1929b. Pteridophyta Novae Caledoniae and new Pteridophytes of Sumatra. Univ. Calif. Publ. Bot. 14: 353.

Domin, K. 1915. Beiträge zur Flora und Pflanzengeographie Australiens. I. Teil, 1. u. 2. Abt. Pteridophyta, etc. Bibl. Bot. 20.

Fournier, E. 1873. Filices Novae-Caledoniae. Enumeratio monographica. Ann. Sci. Nat. V. 18: 253.

Good, R. 1947. The geography of the flowering plants. London.

Guillaumin, A. 1962. Polypodiacées I, in: Rés. Scient. Miss. Franco-Suisse Bot. Nouv. Caléd. (1950-1952). II. Mém. Mus. Nat. Hist. Natur. Sér. B, 8 (3): 196.

1964. Polypodiacées. Ibid. III: 1.

Hieronymus, G. Kleine Mitteilungen über Pteridophyten III. Hedwigia 62: 12.

Holtrum, R. E. 1954. A revised flora of Malaya. II. Ferns of Malaya. Singapore.

KRAMER, K. U. 1957. A revision of the genus Lindsaea in the New World with notes on allied genera. Acta Bot. Neerl. 6: 97.

TArdieu-Blot, M. 1958. Polypodiacées $\left(5_{1}-5_{10}\right)$, in: H. Humbert, Fl. Madag. Com. Paris. 